\title{
Sequential Coherence: A Novel Determinant of Open Innovation Performance
}

\author{
Shanta R. Yapa1, R. Senathiraja1, Jurgen Poesche², Ilkka Kauranen² \\ ${ }^{1}$ Faculty of Management \& Finance, University of Colombo, Colombo, Sri Lanka \\ ${ }^{2}$ Department of Industrial Engineering \& Management, Aalto University, Helsinki, Finland \\ Email: shantayapa@gmail.com
}

How to cite this paper: Yapa, S.R., Senathiraja, R., Poesche, J. and Kauranen, I. (2019) Sequential Coherence: A Novel Determinant of Open Innovation Performance. American Journal of Industrial and Business Management, 9, 1781-1799. https://doi.org/10.4236/ajibm.2019.99117

Received: August 1, 2019

Accepted: September 2, 2019

Published: September 5, 2019

Copyright $\odot 2019$ by author(s) and Scientific Research Publishing Inc. This work is licensed under the Creative Commons Attribution International License (CC BY 4.0).

http://creativecommons.org/licenses/by/4.0/ (c) (i) Open Access

\begin{abstract}
Despite its popularity as a strategy to accelerate innovations there is evidence that open innovation does not always increase innovation performance. Extant literature provides inconsistent and inconclusive arguments in respect of the relationship between open innovation practices and innovation performance. Existing theories mostly have an internal focus and fall short of explaining why some firms succeed in open innovation initiatives and why others fail. Open innovation is about knowledge flows. We argue that boundary conditions matter in innovation performance and sequential coherence can explain why some succeed while others fail in open innovation. A qualitative inquiry we made reveals that sequential coherence that facilitates the knowledge transfer at boundary level influences innovation performance in open innovation initiatives. Sequential coherence is measured through the push and the pull effects by willingness and ability of the participants of teacher firm and the preparedness and ability of the participants from the student firm respectively. We trust that our findings bridge a gap in open innovation literature. These initial findings could be generalized through a quantitative study with larger samples. Managerial implications of the finding is that ability to scan the entire chain of knowledge flow across boundaries and taking corrective measures for any bottlenecks or hindrances observed can bring better results from open innovation initiatives. Further, sequential coherence leads to multiple research opportunities in furthering our knowledge in open innovation.
\end{abstract}

\section{Keywords}

Open Innovation, Innovation Performance, Knowledge Flow, Boundary Conditions, Sequential Coherence

\section{Introduction}

Open innovation (OI) captures the increasing propensity of firms to work across 
their traditional boundaries of operations [1]. According to Chesbrough (2017) openness is a strategy for firms. Openness has become a trend in innovation management [2] and attracted wide academic attention [3]. OI encourages organizations to open up their processes to harness external knowledge to accelerate internal innovations and also to use external paths in early commercialization of them [4]. Although the importance of acquiring external knowledge is widely accepted, how the knowledge flow happens is little understood [5]. Far less is known about with whom to partner in acquiring external knowledge [6]. OI does not always bring higher innovation performance and reasons for this is not adequately addressed in existing literature [7]. Many firms struggle to harness value from OI initiatives [8] [9] as they fail to engage external actors [10]. Challenges that firms face involving external actors in OI have become a popular area for research [11] [12] [13] [14]. The rationale of an organization to select the best partner organization among multiple candidates who are having the required knowledge cannot be explained by existing theories [15] [16] [17].

The objective of this paper is to present our findings from a qualitative inquiry we undertook in answering why OI initiatives do not always lead to higher innovation performance. We address a gap in literature in understanding knowledge flows across boundaries. Open innovation demands permeability of organizational boundaries [18]. Although OI is conceptualized as knowledge inflows and outflows at the level of organizational boundary most research work lacks focus on individuals involved in OI [19]. Managers and academics lack a proper understanding of the mechanisms involving the boundaries of the innovation process [20]. Brunswicker \& Vanhaverbeke (2015) suggest that research on open innovation should investigate the interrelation between boundary conditions and a firm's nature of openness. The boundary can be between partner firm and the lead firm or between internal departments of any organization be it the lead firm or a partner firm. Our findings will further enhance the understanding of factors influencing innovation performance in OI.

\section{Literature Review}

Extant literature on the relationship between open innovation and innovation performance provides inconsistent arguments and inconclusive results [21] [22] [23]. Open innovation is a multifaceted phenomenon [24] that demands understanding across various perspectives and levels of analysis [25]. In respect of determinants, processes and outcomes of OI, examining the emerging perspectives within the organization, outside the organization, between organizations or in the broader context of industries is useful [26]. Networking in OI can be horizontal, vertical, or a combination of these and the corresponding network profile has a significant role in innovation performance [27].

Popular theories and variables used to understand OI include absorptive capacity [28] [29] [30] [31], organizational inertia [32]-[37], search depth and breadth [38] [39] [40] [41], cognitive distance [42] [43] [44] [45] [46], ambidex- 
terity [47] [48] [49] [50] and in-bound and out-bound OI practices [20] [51] [52] [53] [54]. However, these theories mainly focus on internal factors and they do not adequately explain OI practices and differences in innovation performance [23] [55].

Many firms struggle to harness value from OI initiatives [8] [56] as they fail to engage external actors [10]. The interface between respective stakeholders becomes an important study object in boundary-crossing innovation activity [25] [57] [58]. Challenges firms face involving external actors in OI have become a popular area for research [11] [12] [13] [14]. Lane \& Lubatkin (1998) emphasize the importance of examining with whom a firm should partner in acquiring new knowledge.

Open innovation goes beyond the boundaries of the focal firm [58] [59] and recent publications have persistently stressed the necessity of understanding the organizational and contextual factors that moderate the relationship between OI and innovation performance [23]. Key questions to be answered include: How do firms select OI partners [15]? From whom a firm can learn mostly [17]? Why do firms record varying levels of success with different OI partners [23]? What are the reasons for firms to record varying success in different OI projects with the same partners [23] [60]? What factors a firm will consider in selecting OI partners [16]? Therefore, it is apparent that the factors captured by existing OI theories and concepts do not sufficiently explain innovation performance.

Absorptive capacity defined as the ability of an organization to recognize the value of external knowledge, assimilate it and use for commercial ends [28] is often used by researchers in explaining open innovation [52]. It is associated with both inbound and outbound OI practices [61] [62] [63]. Zahra \& George (2002) argue that potential absorptive capacity comprising knowledge acquisition and assimilation and realized absorptive capacity that include transformation and exploitation are capabilities built upon each other to produce dynamic organizational capabilities in order to enhance innovation performance. Desorptive capacity that can be considered as the reverse of absorptive capacity refers to the ability of releasing knowledge to partner firms [64]. Based on the argument that a firm cannot learn equally from all other firms, Lane \& Lubatkin (1998) introduced relative absorptive capacity. They argue that one firm's ability to learn from another firms depends on their 1) knowledge bases, 2) compensation policies and organization structures, and 3) dominant logics. Spithoven et al. (2010), Pilav-Velic et al. (2016), Escribano et al. (2008), De Zubielqui et al. (2016) and Kim et al. (2016) have emphasized the positive relationship between absorptive capacity and innovation performance. Pennings \& Hariento (1992a, 1992b) explain the importance of experience as an internal determinant of absorptive capacity. Nicholas-Nixon (1993) identified that high R\&D investments, in-house expertise and managed communication with partner firms lead to higher absorptive capacity.

Lane \& Lubatkin (1998) explain three methods for learning new external knowledge-passive, active and interactive where each provides a different type 
of external knowledge. They found that a student firm's absorptive capacity depends on 1) the specific type of new knowledge offered by the teacher firm, 2) the similarity between the student and teacher firm's compensation practices and organization structures and 3) the student firm's familiarity with the teacher firm's organizational problems.

\section{Sequential Coherence}

We define sequential coherence as the reciprocal result of the push and pull effects by individuals of a teaching firm and the learning firm respectively that enables knowledge to flow across boundary of firms. We suggest that sequential coherence can be measured through the ability and willingness to teach by the teacher firm participants and the ability and readiness to learn by the participants of the student firm as we observed through the qualitative study done. The approach in sequential coherence is to look at knowledge flows from both the supply side and the demand side. We argue that sequential coherence can explain the relationship between OI initiatives and innovation performance. Much of the inter-organizational learning research use absorptive capacity which assumes a firm can equally learn from any other firm [6]. Assume that firm A needs to acquire external knowledge and both firm $B$ and firm $C$ possess the knowledge firm A is looking for. Who is the best partner for firm A? Can firm A equally learn from firm B or firm C? Absorptive capacity of firm A alone cannot explain this. Therefore, we suggest the use of sequential coherence.

We suggest that sequential coherence enables an organization to make use of its absorptive capacity. The boundary of firms become more porous with OI processes and increased interaction with external actors [65]. Sequential coherence focuses on the boundary conditions required for smooth cross border flow of knowledge and technology in both inbound and outbound OI practices. It focuses not only the ability but also the willingness of both the transferor and the recipient of knowledge. More than a measure of internal abilities, sequential coherence focuses on boundary conditions.

Although not used in organizational studies or OI literature before, sequential coherence is a term used in diverse disciplines such as education, chemistry, physics and software development. Wallace \& Bau (1991) explain two types of coherence namely synchronic coherence and sequential coherence in designing of courses in teaching foreign languages. Synchronic coherence describes how far different courses offered in a program dovetail and be complementary to each other. Sequential coherence describes how the contents taught at the beginning of a course or a program would help the student in understanding similar contents or advance contents later in the course, the program or in practice. Madden-Lombardi et al. (2015) emphasize how sequential coherence can affect the perceived ability of the reader or the listener to form a mental image in paired sentences in both auditory and visual presentations. Among others highlighting the importance of coherence are Svennevig, J. (2000) and Psathas, G. (1992). This suggests the importance of sequential coherence in comprehension 
in knowledge transfer.

Spaceor transverse coherence and temporal or sequential coherence [66] [67] are described in physics. Coherence is explained as a fixed relationship between the phases of waves in a beam of radiation of a single frequency. Coherence is explained in chemistry as the togetherness of molecules in forming water drops or any substance. Sequential coherence is explained in software development to highlight the importance of the ability of each component to integrate with the next component to give the desired outcome from the solution. We propose to use the term sequential coherence in explaining relationship between OI and innovation performance. We argue that by examining and influencing the degree of sequential coherence practicing managers may influence innovation performance in OI initiatives.

\section{Why Sequential?}

The life cycle of innovation commences with exploration and ends with exploitation [47]. Exploration generates new knowledge that will enable firms to introduce disruptive innovations and exploitation helps to early industrialize and commercialize them [50]. OI usually begins with inbound activities through which new knowledge is acquired and integrated with existing knowledge [5]. It then spreads across the internal value chain from $\mathrm{R} \& \mathrm{D}$ to manufacturing and operations of the organization. Outbound OI refers to the transmission of knowledge or technology to an external environment [68] [69]. In transmitting technology to the external environment organizations mainly export technical knowhow [70] [71] [72], knowledge [70] and intellectual property [70] [73] [74]. Outbound OI enables the organization to use external paths for early commercialization where the internal knowledge is transferred to outside entities [52] [69]. Similarly, the process may begin with outbound OI which prompts an organization to innovate to meet the demands of the external party ready to commercialize. The organization may then look for external knowledge to innovate through inbound OI activities [51] [75] [76] [77].

The innovation problem that demands a solution may vary through the product development process [78] [79]. Some firms may be very active at the early stages and some may be very active in the later stages in the collaboration with partners [5]. We argue that these variances at idea, implementation and commercialization stages can be explained through sequential coherence.

Purposive management of knowledge flows across boundaries is necessary in OI [5] [26] and we argue that sequential coherence can explain and ensure a smooth knowledge flow. Managers should carefully examine sequential coherence between the lead firm of OI and each partner firm to achieve the expected innovation performance. As the strength of a chain is defined and constrained by the strength of its weakest link, sequential coherence of each boundary in the knowledge flow matters in ensuring a smooth flow of knowledge. It is through regular scans of the chain of knowledge flow managers can identify any draw- 
backs, bottlenecks and hindrances to take corrective action. Firm A being the lead firm cooperates with firm B as inbound OI partner to access knowledge. Sequential coherence between firm A and firm B matters in ensuring the knowledge flow happens. Similarly, firm A works with firm C as the outbound OI partner where firm $\mathrm{C}$ will assist firm A to early commercialize their innovations. The sequential coherence between firm $\mathrm{A}$ and firm $\mathrm{C}$ is important to ensure the knowledge flow to achieve the desired innovation performance. We argue that any hindrance of sequential coherence between firms may affect innovation performance.

\section{Absorptive Capacity and Sequential Coherence}

Absorptive capacity is considered as a critical resource that depends on the prior knowledge of a firm and determines the firm's innovative capabilities [64]. Nonaka \& Takeuchi (1995) describe knowledge as the result of the interaction between the actors; the transferor and the recipient. We argue that in order to transfer knowledge both the ability and willingness of the transferor and recipient will matter. In this context, sequential coherence compliments absorptive capacity in acquiring knowledge. Internal R\&D capabilities are indispensable in effectively exploiting external knowledge [28] [80]. It is important to understand the internal organization of the innovation process which determines diffusion and exploitation of technical knowledge within the organization [46] [81] [82]. Lakemond et al. (2016) describe the importance of firm's choice of knowledge governance in innovation performance. Bogers et al. (2017) emphasize the importance of the roles played by individuals who are assigned with various tasks in OI in ensuring innovation performance. Heath and Staudenmaier (2000) describe that in accomplishing work, organizations should motivate employees so that their goals are aligned (the agency problem) and should organize the individuals so that their actions are aligned (the coordination problem).

We argue that sequential coherence can be considered as an add-on to absorptive capacity to better understand the knowledge flow from one person to another across boundaries in organizations in OI partner firms, departments and work teams. In each point of knowledge transfer the push and pull effect created by the willingness and ability of the participant from teacher firm and the ability and preparedness of the participant from the student firm impact the result. Vanhaverbeke \& Cloodt (2014) explain that absorptive capacity explains only the inbound OI process and it does not pay attention to outbound OI. Sequential coherence can bridge this gap as it addresses seamless knowledge transfer across the value chain from inbound OI, internal knowledge transfer and outbound OI. In this regard, the unit of analysis in using sequential coherence may be the organization or the entire network of OI relationships.

\section{The Grounded Theory Approach}

In grounded theory approach of qualitative research set procedures are used in 
analysis [83]. As advanced by Corbin and Strauss (1990) it comprises open, axial and selective coding. Open coding refers to a procedure for developing categories of information whereas axial coding refers to interconnecting the categories. Selective coding refers to building a story that connects the categories to end with a discursive set of theoretical propositions [84].

OI practices are popular among business organizations in Sri Lanka [85] and we selected five different case studies from Sri Lanka in this research. They include 1) a startup IoT firm offering automation solutions to manufacturing firms, 2) an award winning SME level software firm catering to banking and financial services industry, 3) a startup firm by three university students attempted to commercialize a medical innovation, 4) a subsidiary of a well-established software company trying to commercialize an automatic accident notification system and 5) a local brand of mobile phones where the products are outsourced from China as per the in-house designs. We have used substitute names for the firms to hide the identity.

The first review of data collected from the lengthy discussions and interviews with the key people in those five firms enabled us to identify general categories such as strategic factors, leadership and human factors that influence knowledge flow. Creswell (1998) describes this as open coding. Goal alignment and complementarity in interests are the findings under strategic factors. Flexibility and managerial support are findings under the leadership category. Our phenomenon of interest which is boundary conditions were mostly explained through human factors. Further analysis on this described as axial coding [83] revealed that ability and willingness to share knowledge by teacher firm and the ability and preparedness to learn by the student firm are the factors influencing the knowledge flow. Given below are excerpts pertaining to sequential coherence from the different firms.

\subsection{Case 1}

Robosol is a small business firm in to designing, developing and implementation of process automation solutions using robotics and IoT for manufacturing firms. They successfully implemented several solutions including robotics process automation in leading corporate firms. As they cater to diverse sectors, the limited number of employees at Robosol has to acquire knowledge in an array of disciplines. They mostly partnered with a leading engineering university in acquiring new knowledge. The managing director of the company highlighted the necessity of being very specific in acquiring new knowledge from their buyers as well as from other institutions as redundant knowledge is a cost. Following excerpts from him explains this further.

Unlike in the case of an invention where extensive $R \& D$ happens, in innovations we combine existing technology and knowledge from various sources to add more value to our product. It can be an attempt to differentiate the product or adding a new functionality or an enhancing performance. Therefore, in innovations what is crucial is acquiring the required knowledge from the right part- 
ner. In doing so, you have to have the right team to interact with the partner firms, be flexible and adaptable to strange situations to get your work done. The soft skills the innovation team possesses in working with diverse innovation partners such as universities, $R \& D$ firms, laboratories, suppliers and buyers are very vital to succeed. Because, each partner has their own way of working as cultures are different. The challenge to us is assigning the most suitable people desirous of learning from our organization to work with the people from the partner firms who are desirous of teaching. We got the right people from the university staff who never had any hesitation in explaining and transferring knowledge.

The following is an excerpt from the project manager in-charge of one of the major automation solutions they deployed.

We had two knowledge partners, a leading university and a research institute. We also had a marketing partner who also part funded the project. Compared to the size of our company with nearly 25 employees all our partners had employees several folds higher than us. Signing a collaboration agreement does not mean to say that all my fifty plus employees will work with 500 people of the university. Who can lead our team involved in the project will be quite crucial in getting the knowledge transferred. You need to select people who are passionate to learn, motivated, willing to understand cultural differences, adoptable to situations, enjoy working with outsiders etc. If you fail to do this match making with the partner firms failure is guaranteed irrespective of how strong your collaboration agreement and the desire to work together.

\subsection{Case 2}

Paymode Ltd. realized the importance of external knowledge in coming up with innovations in the domain of secure electronic payments. They partnered with a local university as their inbound OI partner in acquiring new knowledge. Paymode selected one of their customers, a leading bank in the country and known for innovative digital solutions, as their outbound OI partner. The product they jointly developed named slip-less banking was adjudged as one of the best software solutions in the category of banking $\&$ financial services in a national competition. The product also represented Sri Lanka at the Asia Pacific ICT Alliance awards 2018 and won a merit award outperforming 15 other economies. The founder CEO of Paymode had this to say when asked about the secret of success.

In innovating it is quite important to identify the right partners. When you have many similar options it is a challenge to select the most appropriate ones. It was not an accident and we consciously selected the knowledge partner the best known local university for data security. Luckily, there were several resources with adequate exposure in to secure payments, information security and digital forensics. Common interests we shared pushed the project forward smoothly. Similarly, we partnered with the right bank who had the necessity of innovating in the front end activities. When we elaborated paperless deposits and withdrawals they readily accepted to partner with us. There again we assigned the 
right people from our end to work with the employees of our partner firms. Their preparedness to learn and share made it a success and reminded me again that fortune favors the prepared. We ended by introducing the best banking innovation in the country and also bringing glory and fame to the country winning an international award.

This is how the Chief Operating Officer of the company explained the situation.

Acquiring the required knowledge from another organization is not something like you connect a pipe and open the valve so that knowledge flows. People who do belong to various ranks from the organizations take part in the process. Their passion and motivation levels may vary. Out of many potential employees of the knowledge partner the employees assigned from our end know the most appropriate ones to interact with and get the project going. We look for knowledge that is not easily found in books, journals or in the web. More than selecting the person with the best knowledge the one who has the desire to share and the right capability can make a big difference. This is very important as knowledge transfer does not end with one conversation. You got to interact regularly as the learner absorbs and builds new knowledge gradually like the way a wall is constructed by placing bricks one on another.

\subsection{Case 3}

A start up software firm attempted to commercialize a medical innovation co-developed with a leading engineering university faced many challenges. The product monitors environmental conditions which can affect patients especially children with respiratory system related sicknesses such as asthma. A wearable device prompts patients to engage in gaming connected to breathing exercises that enable the doctors to monitor patients closely. This product which was adjudged as the best software solution in the tertiary category at the National Best Quality software Awards 2017 lost its momentum in the process of commercialization with the first partner and switched to another partner with whom they managed to show progress. The following is an excerpt from our discussion with the leader of the team from the startup.

When you look at the overall story from the top, you tend to realize that the knowledge and technology was not flowing smoothly between the university and our start up firm and then to the hospitals and the commercialization partner. We found lots of bottlenecks and challenges in crossing the borders of various departments in the state owned hospital. For an example, the pediatric ward to central nursing department to medical administration the knowledge transfer had to be pushed by us being an external party and the lead partner. It was really like a relay race where baton exchange at the border was not so smooth.

When you work on a project with people from different organizations you face many challenges. When there are various activities lined up with people assigned from the partner firms each individual's role is detrimental to the progress of the project. We started no sooner a formal agreement was signed between our 
company being the innovation partner, the university as the knowledge partner and the state owned hospital as the commercialization partner. Although the team from the hospital was quite dynamic and enthusiastic in pursuing with the goals we had to go through the head of a department who had a completely different attitude towards the project. As the commercialization was planned with a formal budget, we had to abandon the venture halfway as the flow of knowledge across borders was not so smooth. A seamless integration of work, knowledge, technologies of partner firms are essential for success. Then, we were able to sign up with a private hospital and their parent company as our commercialization partner. Since then, the project shows considerable progress.

\subsection{Case 4}

ERI, the subsidiary of a leading software company came up with an automatic accident detection and notification device named auto alert. In a country where a person dies due to a road accident once in 3 hours and where two motorcycle accidents are reported to the police in each hour an innovative solution failed to take off despite the efforts of the company over a period of 18 months.

The product has an electronic device to monitor acceleration, harsh braking and angle of the vehicle and in the case of an accident it sends automatic alert messages to pre-defined numbers with exact location details. They added 8 different features to the product to make it more appealing and development of the electronic circuits and embedded software took a long time. Given below is an excerpt from the discussion with the project manager.

We used experts in electronics and software development and had to interfere quite often in coordination of the activities. We also had to acquire knowledge from the parent company especially with regard to software development and knowledge transfer was never smooth. Although, some were officially entrusted to assist us the objectives and priorities of people from parent company were quite different. Many a times I received complaints from my staff for non-cooperating attitude. Those who are passionate and motivated to perform should be facilitated in a timely manner as they are the ones who are getting frustrated when things are not moving.

The backend software development which facilitates communication between the electronic devices and the main system delayed substantially as we had to wait until we reach certain milestones of the front end work. This was a major challenge. We could not expedite things as it was something like an assembly line operation where progress of one work station directly affects the work in the successive work stations.

\subsection{Case 5}

This is the case of G-Tel, a Sri Lankan brand of mobile phones. They lead the market in Sri Lanka in the feature phones segment and they also export to a few other countries in limited quantities. G-Tel who designs the product usually sources the prototypes as well as commercial quantities from a few selected Chi- 
nese manufacturers. Inability to communicate properly prompted the local and Chinese parties to concentrate only on essential and product related discussion points. The following excerpt from the managing director of the company highlights the role of sequential coherence.

Getting a prototype developed the way we need is not that easy. There are things you cannot include in to a circuit diagram or a drawing. There are instances where I educate each and every player in the development team in the Chinese factory. I transfer the required knowledge to electronics engineer who does the printed circuit board and then to the electronic technician who assembles and does the wave soldering. I also share the required knowledge with the procurement person to ensure the right components are supplied.

Once the prototype is done getting it tested the way we need is another challenge. I need to individually discuss with the testing engineers and share knowledge. When the prototype is ready then it is a matter of getting the enclosure designed. Although, we provide the drawings each element and aspect demands a lot of interaction between us and the people from the factory. If there is a break in the chain of sharing knowledge the whole process gets affected. More than language issues where we use translators to ease communication, it is sharing knowledge with the right people, at the right time is the challenge in innovating with many partners. It is not only the verbal or written communication that matters but also the components, devices and instruments. They communicate better than people in transferring knowledge from one to another.

Key findings pertaining to the knowledge flow at boundary level of the student firms and the teacher firms of the above case studies prompt us to suggest sequential coherence as a factor that can influence innovation performance.

\section{Discussion}

OI is an inherently dynamic process that demands research to incorporate dynamic elements [84]. We argue that sequential coherence is a dynamic measure capable of influencing innovation performance in OI initiatives. Why do some open innovation initiatives lead to higher innovation performance and some fail [23] [55]? Firm $A$ succeeds with firm $B$ in an OI initiative whereas a similar initiative firm $A$ undertakes with firm $C$ fails. If we examine only an ability that is pertaining to firm $A$ we cannot explain why one initiative failed and the other succeeded. We argue that sequential coherence can explain this and it is a pre-condition for absorptive capacity to work in favor of an organization.

Absorptive capacity describes the pulling effect caused by the firm in knowledge transfer and its use [64]. Sequential coherence explains both the pulling effect and pushing effect required for successful knowledge flow between an organization and its OI partner firms. In this context, sequential coherence goes beyond absorptive capacity or desorptive capacity. Sequential coherence explains both the ability and the willingness from both sides of the story namely the teacher firm and student firm by going down to individual level and across organizations. In the case of inbound OI, the pushing effect from partner firm and 
the pulling effect by the focal firm are important. Similarly, in the case of outbound OI, the pushing effect by focal firm and pulling effect by partner firm are important.

Sequential coherence ensures that knowledge will flow smoothly from teacher firm to student firm in an unbroken manner. This transmission may happen through people via discussions, presentations and interactive learning and also through products and processes. Higher social interaction between firms facilitated through multiple ties enhances knowledge acquisition [86]. Naqshbandi (2016) emphasizes the importance of managers to keep in touch with people from different firms in ensuring OI performance. If we compare knowledge flow across partner firms with the current flow of an electric circuit where components are considered as different firms, sequential coherence describes the soldered joints between various components. It is also similar to the cable lugs used in connecting different components. Capacity, performance and specifications of individual components will be of no use if we fail to make the proper connections. As an engineer quickly scans all the soldered joints between different components he assembled in a printed circuit board when it is found not working properly, a manager can examine the knowledge flow at boundaries when things are not moving in OI initiatives as expected. We argue that sequential coherence enables knowledge fusion.

There is growing interest on assessing OI at a more micro level than the organization [8] [19] [87] [88] [89]. However, individual level factors remain relatively ill understood [25]. Most research studies on OI have neglected the human aspect of it [52] [90]. Salter et al. (2014) emphasize the challenges faced by employees in OI initiatives. R\&D employees need to allocate time to innovate within and also outside the firm [88]. We argue that higher sequential coherence leads to improved innovation performance in OI initiatives. Practicing managers may use sequential coherence in influencing innovation performance in open innovation initiatives by taking action to address the four areas highlighted namely willingness and ability of participants from teacher firm and the preparedness and ability of student firm participants. OI research studies show that when adopting OI strategies organizations benefit differently and the reasons for these differences are not explained [91]. We believe that our findings support extant literature and will increase the understanding on OI. We propose to test the new determinant of sequential coherence with a larger sample for generalizing it.

Further, it will be interesting to understand how sequential coherence can address issues of cognitive distance, search depth, organizational inertia and ambidexterity the regularly used variables in explaining innovation performance, through further research. For an example, we may test whether a high degree of sequential coherence influence search depth in OI initiatives. Whether attempting to engage in both inbound and outbound OI simultaneously may lead to waste of resources and efforts will be another area to be researched from a sequential coherence perspective. How sequential coherence can address stickiness 
of knowledge [92] [93] will also be an interesting area for further research. Further, we may examine whether the opportunity for participants from teacher firms to learn from the student firm enhances the knowledge flow from teacher firm to student firm. Finally, a major area future researchers may explore is to study how individual factors such as attitudes, personality, perception and motivation of participants affect sequential coherence.

\section{Acknowledgements}

A paper titled The Role of Sequential Coherence in Open Innovation Performance was presented at the International Conference on Business Research 2019 organized by the Faculty of Business, University of Moratuwa, Sri Lanka and a concise version of this article is published in the research proceedings.

\section{Conflicts of Interest}

The authors declare no conflicts of interest regarding the publication of this paper.

\section{References}

[1] Mina, A., Bascavusoglu-Moreau, E. and Hughes, A. (2014) Open Service Innovation and the Firm's Search for External Knowledge. Research Policy, 43, 853-866. https://doi.org/10.1016/j.respol.2013.07.004

[2] Lopes, A.P.V.B.V. and Carvalho, M.M.D. (2018) Evolution of the Open Innovation Paradigm: Towards a Contingency Conceptual Model. Technological Forecasting \& Social Change, 132, 284-298. https://doi.org/10.1016/j.techfore.2018.02.014

[3] Kim, N., Kim, D.J. and Lee, S. (2015) Antecedents of Open Innovation at the Project Level: Empirical Analysis of Korean Firms. R\&D Management, 45, 411-439. https://doi.org/10.1111/radm.12088

[4] Chesbrough, H. (2003) The Logic of Open Innovation: Managing Intellectual Property. California Management Review, 45, 33-58. https://doi.org/10.1177/000812560304500301

[5] Lakemond, N., Bengtsson, L., Laursen, K. and Tell, F. (2016) Match and Manage: The Use of Knowledge Matching and Project Management to Integrate Knowledge in Collaborative in Bound Open Innovation. Industrial and Corporate Change, 25, 333-352. https://doi.org/10.1093/icc/dtw004

[6] Lane, P.J. and Lubatkin, M. (1998) Relative Absorptive Capacity and Inter-Organizational Learning. Strategic Management Journal, 19, 461-477. https://doi.org/10.1002/(SICI)1097-0266(199805)19:5<461::AID-SMJ953>3.0.CO;2$\mathrm{L}$

[7] Yapa, S.R., Senathiraja, R. and Kauranen, I. (2018) Improving Innovation Performance by Convergence in Open Innovation: Evidence from Software Firms in Sri Lanka. Vidyodaya Journal of Management, 4, 1-33.

[8] Salter, A., TerWal, A.L., Criscuolo, P. and Alexy, O. (2015) Open for Ideation: Individual-Level Openness and Idea Generation in R\&D. Journal of Product Innovation Management, 32, 488-504. https://doi.org/10.1111/jpim.12214

[9] Lee, B., Cho, H.H. and Shin, J. (2015) The Relationship between Inbound Open Innovation Patents and Financial Performance: Evidence from Global Information 
Technology Companies. Asian Journal of Technology Innovation, 23, 289-303. https://doi.org/10.1080/19761597.2015.1120497

[10] Dahlander, L. and Piezunka, H. (2014) Open to Suggestions: How Organizations Elicit Suggestions through Proactive and Reactive Attention. Research Policy, 43, 812-827. https://doi.org/10.1016/j.respol.2013.06.006

[11] Foss, N.J., Laursen, K. and Pedersen, T. (2011) Linking Customer Interaction and Innovation: The Mediating Role of New Organizational Practices. Organization Science, 22, 980-999. https://doi.org/10.1287/orsc.1100.0584

[12] Afuah, A. and Tucci, C.L. (2012) Crowdsourcing as a Solution to Distant Search. Academy of Management Review, 37, 355-375. https://doi.org/10.5465/amr.2010.0146

[13] Felin, T. and Zenger, T.R. (2014) Closed or Open Innovation? Problem Solving and the Governance Choice. Research Policy, 43, 914-925. https://doi.org/10.1016/j.respol.2013.09.006

[14] Hossain, M. and Anees-ur-Rehman, M. (2016) Open Innovation: An Analysis of Twelve Years of Research. Strategic Outsourcing. An International Journal, 9, 22-37. https://doi.org/10.1108/SO-09-2015-0022

[15] West, J. and Gallagher, S. (2006) Challenges of Open Innovation: The Paradox of Firm Investment in Open-Source Software. R\&D Management, 36, 319-331. https://doi.org/10.1111/j.1467-9310.2006.00436.x

[16] Rusanen, H. (2013) Finding the Right Partners for Innovation Networks. In: ISPIM Conference Proceedings, The International Society for Professional Innovation Management (ISPIM), 1.

[17] Von Krogh, G., Netland, T. and Wörter, M. (2018) Winning with Open Process Innovation. MIT Sloan Management Review, 59, 53-56.

[18] Dahlander, L. and Gann, D.M. (2010) How Open Is Innovation? Research Policy, 39, 699-709. https://doi.org/10.1016/j.respol.2010.01.013

[19] Bogers, M., Foss, N.J. and Lyngsie, J. (2018) The "Human Side" of Open Innovation: The Role of Employee Diversity in Firm-Level Openness. Research Policy, 47, 218-231. https://doi.org/10.1016/j.respol.2017.10.012

[20] Enkel, E., Gassmann, O. and Chesbrough, H. (2009) Open R\&D and Open Innovation: Exploring the Phenomenon. R\&D Management, 39, 311-316. https://doi.org/10.1111/j.1467-9310.2009.00570.x

[21] Caputo, M., Lambert, E., Cammarano, A. and Michelino, F. (2016) Exploring the Impact of Open Innovation on Firm Performance. Management Decisions, 54, 1788-1812. https://doi.org/10.1108/MD-02-2015-0052

[22] Cheng, C.C. and Shiu, E.C. (2015) The Inconvenient Truth of the Relationship between Open Innovation Activities and Innovation Performance. Management Decision, 53, 625-647. https://doi.org/10.1108/MD-03-2014-0163

[23] Bengtsson, L., Lakemond, N., Lazzarotti, V., Manzini, R., Pellegrini, L. and Tell, F. (2015) Open to a Select Few? Matching Partners and Knowledge Content for Open Innovation Performance. Creativity and Innovation Management, 24, 72-86. https://doi.org/10.1111/caim.12098

[24] Randhawa, K., Wilden, R. and Hohberger, J. (2016) A Bibliometric Review of Open Innovation: Setting a Research Agenda. Journal of Production \& Innovation Management, 33, 750-772. https://doi.org/10.1111/jpim.12312

[25] Bogers, M., Zobel, A.K., Afuah, A., Almirall, E., Brunswicker, S., Dahlander, L., Frederiksen, L., Gawer, A., Gruber, M., Haefliger, S. and Hagedoorn, J. (2017) The 
Open Innovation Research Landscape: Established Perspectives and Emerging Themes across Different Levels of Analysis. Industry and Innovation, 24, 8-40. https://doi.org/10.1080/13662716.2016.1240068

[26] Chesbrough, H. and Bogers, M. (2014) Explicating Open Innovation: Clarifying an Emerging Paradigm for Understanding Innovation. In: Chesbrough, H., Vanhaverbeke, W. and West, J., Eds., Open Innovation: New Frontiers and Applications, Oxford University Press, Oxford, 3-28.

https://doi.org/10.1093/acprof:oso/9780199682461.003.0001

[27] Hossain, M. and Kauranen, I. (2016) Open Innovation in SMEs: A Systematic Literature Review. Journal of Strategy and Management, 9, 58-73.

https://doi.org/10.1108/JSMA-08-2014-0072

[28] Cohen, W.M. and Levinthal, D.A. (1990) Absorptive Capacity: A New Perspective on Learning and Innovation. Administrative Science Quarterly, 35, 128-152. https://doi.org/10.2307/2393553

[29] Murovec, N. and Prodan, I. (2009) Absorptive Capacity, Its Determinants, and Influence on Innovation Output: Cross-Cultural Validation of the Structural Model. Technovation, 29, 859-872. https://doi.org/10.1016/j.technovation.2009.05.010

[30] De Zubielqui, G.C., Jones, J. and Lester, L. (2016) Knowledge Inflows from Market and Science Based Actors, Absorptive Capacity, Innovation and Performance-A Study of SMEs. International Journal of Innovation Management, 20, Article ID: 1650055. https://doi.org/10.1142/S1363919616500559

[31] Matusik, S.F. and Heeley, M.B. (2005) Absorptive Capacity in the Software Industry: Identifying Dimensions That Affect Knowledge and Knowledge Creation Activities. Journal of Management, 31, 549-572. https://doi.org/10.1177/0149206304272293

[32] Huang, H.C., Lai, M.C., Lin, L.H. and Chen, C.T. (2013) Overcoming Organizational Inertia to Strengthen Business Model Innovation: An Open Innovation Perspective. Journal of Organizational Change Management, 26, 977-1002. https://doi.org/10.1108/JOCM-04-2012-0047

[33] Godkin, L. (2010) The Zone of Inertia: Absorptive Capacity and Organizational Change. The Learning Organization, 17, 196-207. https://doi.org/10.1108/09696471011034900

[34] Chesbrough, H.W. (2006) Open Innovation: The New Imperative for Creating and Profiting from Technology. Harvard Business Press, Boston.

[35] Amabile, T.M., Conti, R., Coon, H., Lazenby, J. and Herron, M. (1996) Assessing the Work Environment for Creativity. Academy of Management Journal, 39, 1154-1184. https://doi.org/10.2307/256995

[36] Matthyssens, P., Vandenbempt, K. and Berghman, L. (2006) Value Innovation in Business Markets: Breaking the Industry Recipe. Industrial Marketing Management, 35, 751-761. https://doi.org/10.1016/j.indmarman.2005.05.013

[37] Nijssen, E.J., Hillebrand, B., Vermeulen, P.A. and Kemp, R.G. (2006) Exploring Product and Service Innovation Similarities and Differences. International Journal of Research in Marketing, 23, 241-251. https://doi.org/10.1016/j.ijresmar.2006.02.001

[38] Laursen, K. and Salter, A. (2006) Open for Innovation: The Role of Openness in Explaining Innovation Performance among UK Manufacturing Firms. Strategic Management Journal, 27, 131-150. https://doi.org/10.1002/smj.507

[39] Cruz-González, J., López-Sáez, P., Navas-López, J.E. and Delgado-Verde, M. (2015) Open Search Strategies and Firm Performance: The Different Moderating Role of 
Technological Environmental Dynamism. Technovation, 35, 32-45. https://doi.org/10.1016/j.technovation.2014.09.001

[40] Garriga, H., Von Krogh, G. and Spaeth, S. (2013) How Constraints and Knowledge Impact Open Innovation. Strategic Management Journal, 34, 1134-1144. https://doi.org/10.1002/smj.2049

[41] Greco, M., Grimaldi, M. and Cricelli, L. (2016) An Analysis of the Open Innovation Effect on Firm Performance. European Management Journal, 34, 501-516. https://doi.org/10.1016/j.emj.2016.02.008

[42] Inauen, M. and Schenker-Wicki, A. (2012) Fostering Radical Innovations with Open Innovation. European Journal of Innovation Management, 15, 212-231. https://doi.org/10.1108/14601061211220986

[43] Gulati, R. (1995) Social Structure and Alliance Formation Patterns: A Longitudinal Analysis. Administrative Science Quarterly, 40, 619-652. https://doi.org/10.2307/2393756

[44] Wuyts, S., Colombo, M.G., Dutta, S. and Nooteboom, B. (2005) Empirical Tests of Optimal Cognitive Distance. Journal of Economic Behavior \& Organization, 58, 277-302. https://doi.org/10.1016/j.jebo.2004.03.019

[45] Nooteboom, B. (2000) Learning by Interaction: Absorptive Capacity, Cognitive Distance and Governance. Journal of Management and Governance, 4, 69-92. https://doi.org/10.1023/A:1009941416749

[46] Nooteboom, B., Van Haverbeke, W., Duysters, G., Gilsing, V. and Van den Oord, A. (2007) Optimal Cognitive Distance and Absorptive Capacity. Research Policy, 36, 1016-1034. https://doi.org/10.1016/j.respol.2007.04.003

[47] March, J.G. (1991) Exploration and Exploitation in Organizational Learning. Organization Science, 2, 71-87. https://doi.org/10.1287/orsc.2.1.71

[48] Tushman, M.L. and O’Reilly, C.A. (1996) The Ambidextrous Organizations: Managing Evolutionary and Revolutionary Change. California Management Review, 38, 8-30. https://doi.org/10.2307/41165852

[49] Andriopoulos, C. and Lewis, M.W. (2009) Exploitation-Exploration Tensions and Organizational Ambidexterity: Managing Paradoxes of Innovation. Organization Science, 20, 696-717. https://doi.org/10.1287/orsc.1080.0406

[50] Ferrary, M. (2011) Specialized Organizations and Ambidextrous Clusters in the Open Innovation Paradigm. European Management Journal, 29, 181-192. https://doi.org/10.1016/j.emj.2010.10.007

[51] Bianchi, M., Croce, A., Dell'Era, C., Di Benedetto, C.A. and Frattini, F. (2015) Organizing for Inbound Open Innovation: How External Consultants and a Dedicated R\&D Unit Influence Product Innovation Performance. Journal of Product Innovation Management, 33, 492-510. https://doi.org/10.1111/jpim.12302

[52] West, J. and Bogers, M. (2014) Leveraging External Sources of Innovation: A Review of Research on Open Innovation. Journal of Product Innovation Management, 31, 814-831. https://doi.org/10.1111/jpim.12125

[53] Fernandes, S., Cesario, M. and Barata, J.M. (2017) Ways to Open Innovation: Main Agents and the Sources in the Portuguese Case. Technology in Society, 51, 153-162. https://doi.org/10.1016/j.techsoc.2017.09.002

[54] Popa, S., Soto-Acosta, P. and Martinez-Conesa, I. (2017) Antecedents, Moderators, and Outcomes of Innovation Climate and Open Innovation: An Empirical Study in SMEs. Technological Forecasting and Social Change, 118, 134-142. https://doi.org/10.1016/j.techfore.2017.02.014 
[55] Cheng, C.C. and Huizingh, E.K. (2014) When Is Open Innovation Beneficial? The Role of Strategic Orientation. Journal of Product Innovation Management, 31, 1235-1253. https://doi.org/10.1111/jpim.12148

[56] Lee, S.M. and Shin, J. (2017) A Path to Collaborative Innovation through Internal Boundary Breaking: Open Innovation Tools Applied within the Organization Helped LG Chem Research Park Build a Culture That Nurtures Collaborative Innovation. Research-Technology Management, 60, 26-32. https://doi.org/10.1080/08956308.2017.1325688

[57] Hargrave, T.J. and Van de Ven, A.H. (2006) A Collective Action Model of Institutional Innovation. Academy of Management Review, 31, 864-888. https://doi.org/10.5465/amr.2006.22527458

[58] Geels, F.W. (2004) From Sectoral Systems of Innovation to Socio-Technical Systems: Insights about Dynamics and Change from Sociology and Institutional Theory. Research Policy, 33, 897-920. https://doi.org/10.1016/j.respol.2004.01.015

[59] Munir, H., Linaker, J., Wnuk, K., Runeson, P. and Regnell, B. (2018) Open Innovation Using Open Source Tools: A Case Study at Sony Mobile. Empr Software Engineering, 23, 186-233. https://doi.org/10.1007/s10664-017-9511-7

[60] Powell, W.W., Koput, K.W. and Smith-Doerr, L. (1996) Interorganizational Collaboration and the Locus of Innovation: Networks of Learning in Biotechnology. Administrative Science Quarterly, 41, 116-145. https://doi.org/10.2307/2393988

[61] Cassiman, B. and Valentini, G. (2015) Open Innovation: Are Inbound and Outbound Knowledge Flows Really Complementary? Strategic Management Journal, 37, 1034-1046. https://doi.org/10.1002/smj.2375

[62] Spithoven, A., Clarysse, B. and Knockaert, M. (2011) Building Absorptive Capacity to Organise Inbound Open Innovation in Traditional Industries. Technovation, 31, 10-21. https://doi.org/10.1016/j.technovation.2010.10.003

[63] Nitzsche, P., Wirtz, B.W. and Göttel, V. (2016) Innovation Success in the Context of Inbound Open Innovation. International Journal of Innovation Management, 20, Article ID: 1650025. https://doi.org/10.1142/S1363919616500250

[64] Vanhaverbeke, W. (2006) The Interorganizational Context of Open Innovation. In: In: Chesbrough, H., Vanhaverbeke, W. and West, J., Eds., Open Innovation: Researching a New Paradigm, Oxford University Press, Oxford, 205-219.

[65] Dell'Anno, D. and Del Giudice, M. (2015) Absorptive and Desorptive Capacity of Actors within University-Industry Relations: Does Technology Transfer Matter? Journal of Innovation and Entrepreneurship, 4, 13. https://doi.org/10.1186/s13731-015-0028-2

[66] Mandel, L. and Wolf, E. (1965) Coherence Properties of Optical Fields. Reviews of Modern Physics, 37, 231. https://doi.org/10.1103/RevModPhys.37.231

[67] Roling, S., Siemer, B., Wöstmann, M., Zacharias, H., Mitzner, R., Singer, A. and Vartanyants, I.A. (2011) Temporal and Spatial Coherence Properties of Free-Electron-Laser Pulses in the Extreme Ultraviolet Regime. Physical Review Special Topics-Accelerators and Beams, 14, Article ID: 080701. https://doi.org/10.1103/PhysRevSTAB.14.080701

[68] Huizing, E.K.R.E. (2011) Open Innovation: State of the Art and Future Perspectives. Technovation, 31, 2-9. https://doi.org/10.1016/j.technovation.2010.10.002

[69] Hung, K.P. and Chou, C. (2013) The Impact of Open Innovation on Firm Performance: The Moderating Effects of Internal R\&D and Environmental Turbulence. Technovation, 33, 368-380. https://doi.org/10.1016/j.technovation.2013.06.006

[70] Naqshbandi, M.M. (2016) Managerial Ties and Open Innovation: Examining the 
Role of Absorptive Capacity. Management Decision, 54, 2256-2276. https://doi.org/10.1108/MD-03-2016-0161

[71] Parida, V., Westerberg, M. and Frishammar, J. (2012) Inbound Open Innovation Activities in High-Tech SMEs: The Impact on Innovation Performance. Journal of Small Business Management, 50, 283-309. https://doi.org/10.1111/j.1540-627X.2012.00354.x

[72] Cassiman, B. and Veugelers, R. (2006) In Search of Complementarity in Innovation Strategy: Internal R\&D and External Knowledge Acquisition. Management Science, 52, 68-82. https://doi.org/10.1287/mnsc. 1050.0470

[73] Tsai, C.T. and Liao, W.F. (2011) A Study on the Framework and Indicators for Open Innovation Performance via AHP Approach. Technology Management in the Energy Smart World, Portland, 31 July-4 August 2011, 1-7.

[74] Cheng, C.C., Yang, C. and Sheu, C. (2016) Effects of Open Innovation and Knowledge-Based Dynamic Capabilities on Radical Innovation: An Empirical Study. Journal of Engineering and Technology Management, 41, 79-91. https://doi.org/10.1016/j.jengtecman.2016.07.002

[75] Kim, B., Kim, E. and Foss, N.J. (2016) Balancing Absorptive Capacity and Inbound Open Innovation for Sustained Innovative Performance: An Attention-Based View. European Management Journal, 34, 80-90. https://doi.org/10.1016/j.emj.2015.10.002

[76] Lopez-Vega, H., Tell, F. and Vanhaverbeke, W. (2016) Where and How to Search? Search Paths in Open Innovation. Research Policy, 45, 125-136.

https://doi.org/10.1016/j.respol.2015.08.003

[77] Cooper, R.G. (2008) Perspective: The Stage-Gate ${ }^{\circledast}$ Idea-to-Launch Process-Update, What's New, and NexGen Systems. Journal of Product Innovation Management, 25, 213-232. https://doi.org/10.1111/j.1540-5885.2008.00296.x

[78] Grönlund, J., Sjödin, D.R. and Frishammar, J. (2010) Open Innovation and the Stage-Gate Process: A Revised Model for New Product Development. California Management Review, 52, 106-131. https://doi.org/10.1525/cmr.2010.52.3.106

[79] Vanhaverbeke, W. and Cloodt, M. (2014) Theories of the Firm and Open Innovation. In: New Frontiers in Open Innovation, Oxford University Press, Oxford, 256-278. https://doi.org/10.1093/acprof:oso/9780199682461.003.0014

[80] Levinthal, D.A. and March, J.G. (1993) The Myopia of Learning. Strategic Management Journal, 14, 95-112. https://doi.org/10.1002/smj.4250141009

[81] Argyres, N.S. and Silverman, B.S. (2004) R\&D, Organization Structure, and the Development of Corporate Technological Knowledge. Strategic Management Journal, 25, 929-958. https://doi.org/10.1002/smj.387

[82] Creswell, J.W. (1998) Qualitative Inquiry and Research Design: Choosing among Five Traditions.

[83] Appleyard, M.M. and Chesbrough, H.W. (2017) The Dynamics of Open Strategy: From Adoption to Reversion. Long Range Planning, 50, 310-321. https://doi.org/10.1016/j.lrp.2016.07.004

[84] Strauss, A. and Corbin, J.M. (1990) Basics of Qualitative Research: Grounded Theory Procedures and Techniques. Sage Publications, Inc., Thousand Oaks.

[85] Yapa, S.R. and Senathiraja, R. (2017) Inbound Open Innovation: Whom to Converge with and Why? In: International Conference on the Humanities and the Social Sciences, University of Peradeniya, Sri Lanka.

[86] Yli-Renko, H., Autio, E. and Sapienza, H.J. (2001) Social Capital, Knowledge Acqui- 
sition, and Knowledge Exploitation in Young Technology-Based Firms. Strategic Management Journal, 22, 587-613. https://doi.org/10.1002/smj.183

[87] Du, J., Leten, B. and Vanhaverbeke, W. (2014) Managing Open Innovation Projects with Science-Based and Market-Based Partners. Research Policy, 43, 828-840. https://doi.org/10.1016/j.respol.2013.12.008

[88] Dahlander, L., O’Mahony, S. and Gann, D.M. (2016) One Foot in, One Foot out: How Does Individuals' External Search Breadth Affect Innovation Outcomes? Strategic Management Journal, 37, 280-302. https://doi.org/10.1002/smj.2342

[89] Ahn, J.M., Minshall, T. and Mortara, L. (2017) Understanding the Human Side of Openness: The Fit between Open Innovation Modes and CEO Characteristics. $R \& D$ Management, 47, 727-740. https://doi.org/10.1111/radm.12264

[90] Gassmann, O., Enkel, E. and Chesbrough, H. (2010) The Future of Open Innovation. R\&D Management, 40, 213-221. https://doi.org/10.1111/j.1467-9310.2010.00605.x

[91] Saebi, T. and Foss, N.J. (2015) Business Models for Open Innovation: Matching Heterogeneous Open Innovation Strategies with Business Model Dimensions. European Management Journal, 33, 201-213. https://doi.org/10.1016/j.emj.2014.11.002

[92] Szulanski, G. (1995) Unpacking Stickiness: An Empirical Investigation of the Barriers to Transfer Best Practice inside the Firm. Academy of Management Proceedings, 1995, 437-444. https://doi.org/10.5465/ambpp.1995.17536715

[93] Szulanski, G. (2002) Sticky Knowledge: Barriers to Knowing in the Firm. SAGE Publications, Thousand Oaks. 